\title{
Big data from tiny flies: patterns revealed from over 42,000 phorid flies (Insecta: Diptera: Phoridae) collected over one year in Los Angeles, California, USA
}

\author{
Brian V. Brown ${ }^{1}$ Emily A. Hartop ${ }^{1}$ \\ Published online: 1 December 2016 \\ (C) The Author(s) 2016. This article is published with open access at Springerlink.com
}

\begin{abstract}
The first ever large-scale inventory of an urban phorid fly fauna is described. Collections from 30 Malaise traps from urban Los Angeles over one year from the BioSCAN Project document the presence of 99 species from 42,480 specimens identified. Species accumulation curves predict $102-106$ species actually occurring in this area. Collections are overwhelmingly dominated by the North American fungus feeding species Megaselia agarici, which accounts for about one quarter of all specimens identified. Percentage of $M$. agarici per site ranges from approximately $4 \%$ to $75 \%$. Diversity varied significantly among sites, with species richness per site ranging from 23 to 82 . Implications of patterns of abundance, diversity, and size are discussed.
\end{abstract}

Keywords Urban biodiversity $\cdot$ Flies $\cdot$ Fungivory $\cdot$ Inventory

\section{Introduction}

The Phoridae are a large family of small flies found worldwide (Fig. 1). Although poorly known everywhere, largely because of their diminutive size $(0.4-5.0 \mathrm{~mm})$, phorids are highly diverse in both species numbers and in lifestyles. The

Electronic supplementary material The online version of this article (doi:10.1007/s11252-016-0612-7) contains supplementary material, which is available to authorized users.

Brian V. Brown

phoridae@hotmail.com

1 Urban Nature Research Center, Natural History Museum of Los Angeles County, 900 Exposition Boulevard, California, Los Angeles 90007, USA approximately 4000 known species worldwide, representing perhaps as little as $10 \%$ of the true diversity, are known to be variously scavengers, predators, herbivores, fungivores, parasitoids, and true parasites (reviewed by Disney 1994).

Because of their small size and difficulties in identification, relatively little has been done to study the ecology of phorid flies. This is unfortunate, as phorids make excellent biodiversity study subjects (Disney and Durska 2008). They are diverse within a site, are easily sampled, and use a wide variety of ecosystem resources based on the profusion of different larval and adult lifestyles. Their only disadvantages are their relatively small size and public ignorance of their existence. Good microscopes help the former, while outreach can influence the latter. The fact that phorids are small and poorly-known did not prevent our description of 30 new species from Los Angeles (Hartop et al. 2015) from being covered by the news departments of everything from The New Yorker to Science magazine (Twilley 2015, Fahrenkamp-Uppenbrink 2015)!

Recently, ecological studies on phorids have concentrated on the species of genus Pseudacteon Coquillett that attack invasive fire ants (Solenopsis spp.), offering possibilities of biological control. Other interesting work has been done on the parasitic phorids in the genus Apocephalus Coquillett that attack honey bees (Core et al. 2012) and various ants (LeBrun 2005, Bragança et al. 2008, LeBrun et al. 2009). Communitylevel studies of entire phorid faunas, or even species lists for many sites, however, are much less common. Those of urban faunas are almost non-existent. Exceptions are the studies of phorid ecology by Ewa Durska (Durska 1981, 1996, 2001, 2002, 2003, Durska et al. 2005, Durska 2006, Disney and Durska 2008), including one (Durska 1981) on the urban fauna of Warsaw, Poland. There, she contrasted catches from parks, green areas of housing estates, and the urban center. It is difficult to contrast this study with ours because the 


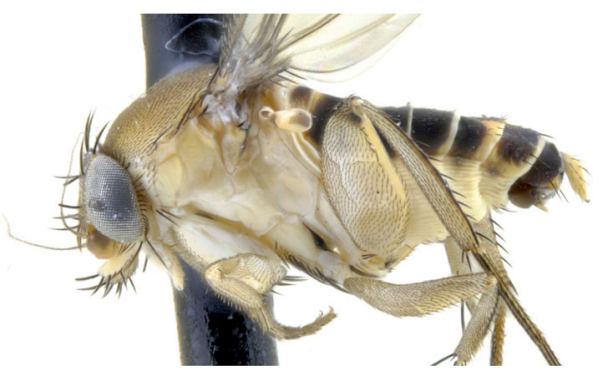

Fig. 1 A male phorid fly, Megaselia scalaris. Actual length of this fly is approximately $2 \mathrm{~mm}$

collecting method was pan trapping from tree crowns and the total number of species was relatively small (36). Additionally, much has happened in the taxonomy of phorids since 1981, and some species, such as "Megaselia pulicaria", are now known to be species complexes. Still, she found reduced diversity in the downtown center.

In this paper, we examine and characterize the phorid fauna of urban Los Angeles, California, USA, as a contribution to basic knowledge, as well as a prelude to further studies in preparation on the "natural" and human-influenced factors that affect the distribution of these flies. This work is part of the BioSCAN Project, an ongoing urban biodiversity survey of the insect fauna of Los Angeles (Brown et al. 2014). The dynamic nature of the urban fauna, with frequent introductions of species due to human commerce, coupled with the increasing urbanization of land and human populations make such studies highly relevant to urban planning. "Green" city initiatives, "sustainability", and basic conservation all need data like these to make rational decisions towards healthier, more biodiverse, living spaces.

\section{Methods and materials}

Insects were collected from a series of Malaise traps placed in 26 backyards, one schoolyard, one community garden, the grounds of the Los Angeles Ecovillage, and the Nature Gardens of the Natural History Museum of Los Angeles County, all in Los Angeles, California, USA (Table 1, Fig. 2). Traps were of the Townes lightweight model (Townes 1972) purchased from Sante traps. These traps were situated in a roughly northeast-southwest swath (Fig. 3). No attempt was made to strictly choose certain types of yard or planting. Each site is briefly described in the Supplementary Materials, and a satellite image is included.

Traps were operated continuously for one year (2014), with the collecting bottle changed weekly. Because of the overwhelming number of specimens, we here include analysis done from only one sample (the first) from each month, a total of 42,480 specimens from 360 samples examined (12 months $\times 30$ sites). The rest of the samples
Table 1 BioSCAN sites

\begin{tabular}{|c|c|c|c|}
\hline Site & Elevation & Latitude & Longitude \\
\hline 1 & 54 & 34.018 & -118.288 \\
\hline 2 & 218.3 & 34.083 & -118.196 \\
\hline 3 & 62 & 34.034 & -118.281 \\
\hline 4 & 222.2 & 34.118 & -118.284 \\
\hline 5 & 166.1 & 34.093 & -118.274 \\
\hline 6 & 199 & 34.116 & -118.279 \\
\hline 7 & 158.9 & 34.102 & -118.257 \\
\hline 8 & 53 & 34.030 & -118.327 \\
\hline 9 & 106.7 & 34.103 & -118.243 \\
\hline 10 & 38 & 34.014 & -118.321 \\
\hline 11 & 85.6 & 34.073 & -118.291 \\
\hline 12 & 52.6 & 34.047 & -118.334 \\
\hline 13 & 245.4 & 34.149 & -118.217 \\
\hline 14 & 149 & 34.078 & -118.234 \\
\hline 15 & 9 & 33.876 & -118.288 \\
\hline 16 & 100 & 34.095 & -118.334 \\
\hline 17 & 190 & 34.159 & -118.246 \\
\hline 18 & 76 & 34.077 & -118.320 \\
\hline 19 & 41.1 & 34.059 & -118.369 \\
\hline 20 & 174.7 & 34.112 & -118.293 \\
\hline 21 & 158 & 34.170 & -118.308 \\
\hline 22 & 133.5 & 34.074 & -118.264 \\
\hline 23 & 119 & 34.114 & -118.251 \\
\hline 24 & 215 & 34.136 & -118.194 \\
\hline 25 & 70 & 34.046 & -118.276 \\
\hline 26 & 58.7 & 34.058 & -118.328 \\
\hline 27 & 186.8 & 34.111 & -118.230 \\
\hline 28 & 160.7 & 34.129 & -118.215 \\
\hline 29 & 205.6 & 34.123 & -118.193 \\
\hline 30 & 227.8 & 34.125 & -118.189 \\
\hline 31 & 74 & 34.103 & -118.216 \\
\hline 32 & 53.7 & 34.017 & -118.289 \\
\hline
\end{tabular}

were stored for future use as comparative material or to provide further specimens of rare species. Some additional, shorter term, collecting was done on 1) property of City Hall in the downtown core, 2) the top of a 3 story building with a garden roof $1 / 2$ mile from City Hall, and 3) on top of the over 1000-ft-tall US Bank building in the heart of downtown. These additional sites were surveyed for shorter periods in 2015 or 2016, and are discussed separately in the results below.

Specimens were collected into, sorted, and identified in $95 \%$ ethanol. Some specimens were dried using hexamethyldisilazane (HMDS) (Brown 1993) or slidemounted following the method of Disney (2006a) for further examination. Holotypes of new species were mounted in Canada balsam, paratypes were mounted in Berlese's 

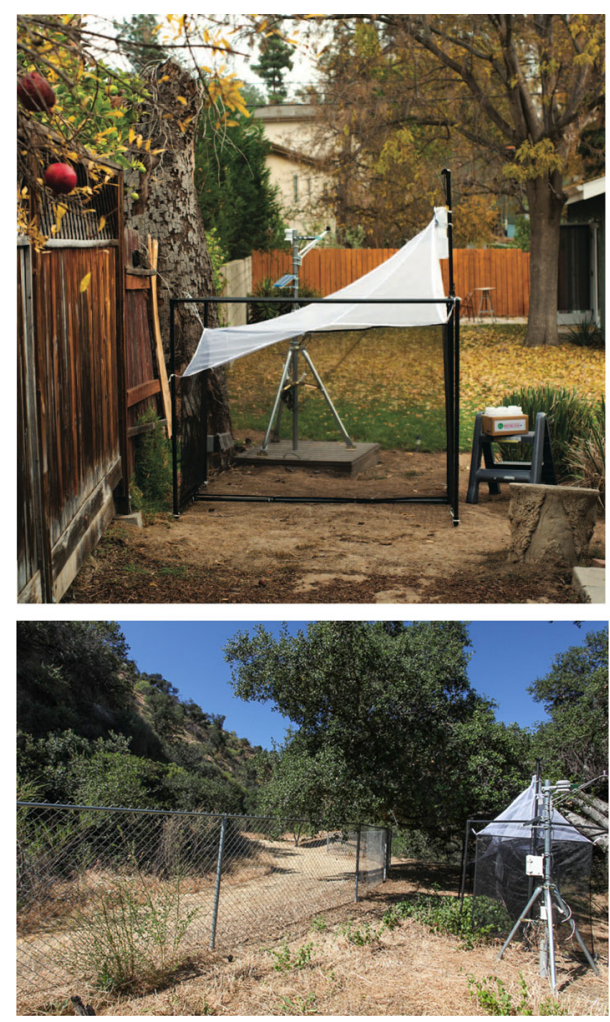

Fig. 2 BioSCAN backyards with Malaise traps

fluid. Holotypes and paratypes are retained in the Entomology collection of the Natural History Museum of Los Angeles County (LACM), with additional paratypes going to the Cambridge University Museum of Zoology. Non-type phorid material from BioSCAN is currently housed at the LACM separately from the rest of the Entomology collection. Boxes of identified slide-mounted material and a small number of dried specimens exist, but the bulk of the identified material was tallied while in ethanol and remained pooled with the rest of the sample.
Map figures and supplementary images were created using Google Earth with use of the Maps Icons Collection (https://mapicons.mapsmarker.com).

Species were classified as urban avoiders (McKinney 2002, = "rural" taxa of McIntyre 2000) if they occurred in no more than one of the downtown core sites $(1,3,8,10,11$, 12, 18, 25, 26 - Fig. 3).

Diversity statistics were calculated using EstimateS (Colwell 1997). Species occurrence correlations were calculated using Microsoft EXCEL. Significance of differences of mean species catch per site were calculated using STATISTICS CALCULATOR; variability among sites was assessed using the F-ratio from an ANOVA, and differences between pairs of sites were examined using post hoc least significant difference t-tests.

\section{Results}

\section{General characterization of the fauna}

Study of the 360 samples yielded 42,480 phorid flies of 99 species (Table 2), 43 (43\%) of which were new to science (Hartop et al. 2015, 2016a, Hartop et al. 2016b). By far the most abundant species was Megaselia agarici, which alone accounted for roughly one quarter of all phorid flies encountered. The second most common species, M. sulphurizona, accounted for only about $12 \%$. Five species, M. agarici, M. lombardorum, M. nigra, M. sulphurizona, and $M$. wiegmanae, were collected at all sites, but sixteen species were collected from only one site, followed by 11 species at two sites (Figs. 4, 11).

The species composition at sites varied widely, from 82 species at site 13 to 19 species at site 8 (Table 3). A visualization of this data can be seen in Fig. 5, where the biodiversity at
Fig. 3 Site map for BioSCAN sampling in Los Angeles, California showing full transect (left) and a close-up of the main cluster of sites (right). BioSCAN Phase I trap sites shown in green, supplementary trapping sites shown in purple. A: City Hall, B: Angel City Brewery, C: US Bank tower
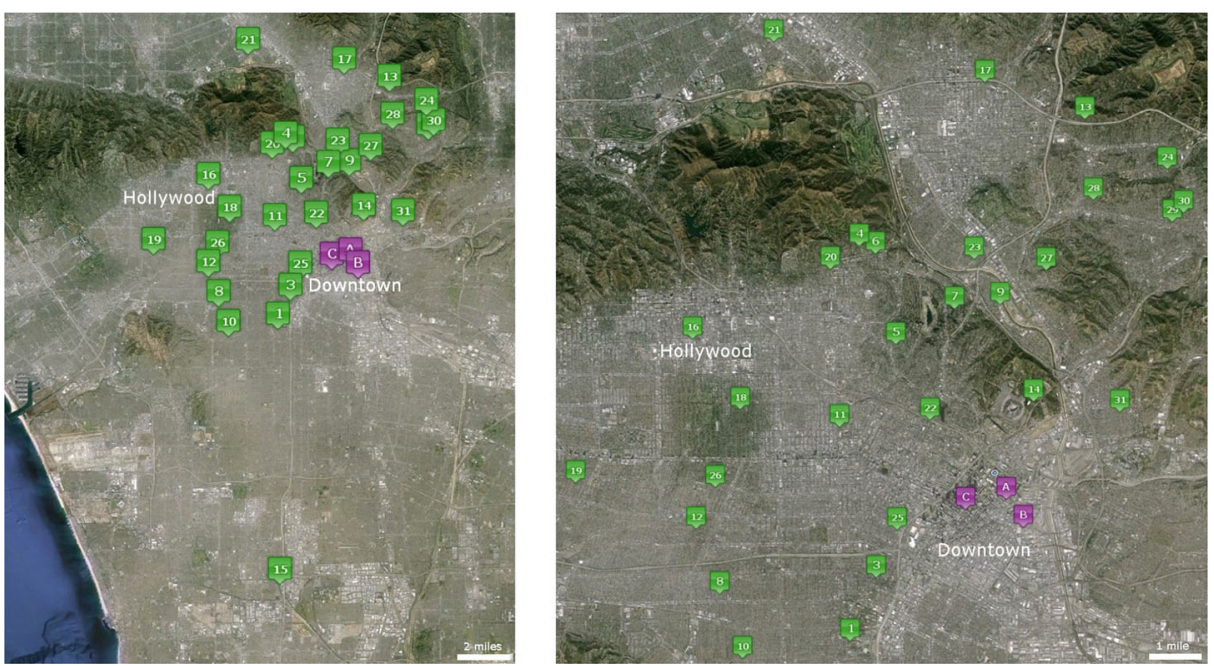
Table 2 Numbers of 99 phorid species collected in survey. Asterisk (*) indicates potentially introduced species (known from elsewhere). Carat $\left.{ }^{\wedge}\right)$ indicates urban avoiders. LA ${ }^{(L . A .}$. $)$ indicates species new to science described from the BioSCAN Project

\begin{tabular}{|c|c|}
\hline Megaselia agarici * & 10,890 \\
\hline Megaselia sulphurizona & 4233 \\
\hline Megaselia nigra $*$ & 3815 \\
\hline Megaselia lombardorum ${ }^{\text {L.A. }}$ & 3074 \\
\hline Megaselia wiegmanae ${ }^{L . A .}$ & 2244 \\
\hline Megaselia marquezi ${ }^{L . A .}$ & 1715 \\
\hline Megaselia oxboroughae ${ }^{L . A .}$ & 1509 \\
\hline Megaselia armstrongorum ${ }^{\text {L.A. }}$ & 1428 \\
\hline Megaselia halterata * & 1349 \\
\hline Megaselia steptoeae ${ }^{L . A .}$ & 1135 \\
\hline Megaselia largifrontalis & 1047 \\
\hline Chonocephalus bentacaise * & 805 \\
\hline Megaselia pleuralis * & 658 \\
\hline Megaselia barberi & 645 \\
\hline Megaselia sidneyae ${ }^{\text {L.A. }}$ & 642 \\
\hline Conicera similis * & 519 \\
\hline Puliciphora virginiensis & 387 \\
\hline Megaselia mikejohnsoni ${ }^{L . A .}$ & 372 \\
\hline Megaselia albicaudata * & 357 \\
\hline Megaselia carthayensis ${ }^{L . A .}$ & 350 \\
\hline Megaselia berndseni * & 335 \\
\hline Megaselia hoggorum $\wedge^{\wedge}$ L.A. & 321 \\
\hline Megaselia fujiokai ${ }^{L . A .}$ & 305 \\
\hline Megaselia creasoni ${ }^{L . A .}$ & 293 \\
\hline Megaselia hansonix & 293 \\
\hline Megaselia pisanoi $\wedge^{\wedge}$ L.A. & 266 \\
\hline Phalacrotophora halictorum & 258 \\
\hline Megaselia sacatelensis L.A. & 238 \\
\hline Megaselia rufipes * & 205 \\
\hline Megaselia francoae $e^{L . A .}$ & 202 \\
\hline Megaselia arizonensis & 178 \\
\hline Beckerina sp. 1 & 177 \\
\hline Megaselia tecticauda $\wedge$ & 177 \\
\hline Megaselia basispinata * & 172 \\
\hline Dohrniphora cornuta * & 171 \\
\hline Megaselia heini ${ }^{L . A .}$ & 161 \\
\hline Trophodeinus furcatus & 153 \\
\hline Megaselia donahuei ${ }^{L . A .}$ & 150 \\
\hline Conicera tibialis $*$ & 144 \\
\hline Metopina $\mathrm{sp}$ & 141 \\
\hline Megaselia atrox * & 119 \\
\hline Megaselia isaacmajorum ${ }^{\wedge}$ L.A. & 110 \\
\hline Megaselia kelleri ${ }^{\text {L.A. }}$ & 101 \\
\hline Megaselia scalaris * & 75 \\
\hline Anevrina variabilis ${ }^{\wedge}$ & 71 \\
\hline Spiniphora bergenstammii * & 60 \\
\hline Megaselia renwickorum ${ }^{\text {L.A. }}$ & 47 \\
\hline Megaselia hoguei $\wedge^{\wedge L . A .}$ & 45 \\
\hline Megaselia rodriguezorum ${ }^{\wedge}$ L.A. & 32 \\
\hline Megaselia hentschkeae ${ }^{L . A .}$ & 31 \\
\hline Megaselia hirticaudata & 31 \\
\hline Megaselia wongae $\wedge^{\text {L.A. }}$ & 31 \\
\hline Megaselia modesta & 30 \\
\hline Diplonevra setigera & 30 \\
\hline Megaselia sordida * & 27 \\
\hline Megaselia ruficornis $*$ & 26 \\
\hline Megaselia hardingorum $\wedge$ L.A. & 23 \\
\hline Megaselia ilca & 21 \\
\hline Trophodeinus arizonensis ${ }^{\wedge}$ & 19 \\
\hline Megaselia ciancii ${ }^{\wedge}$ L.A. & 15 \\
\hline Megaselia defibaughorum ${ }^{L . A}$. & 14 \\
\hline Pseudacteon amuletum ${ }^{\wedge}$ & 12 \\
\hline Microselia sp. $\wedge$ & 11 \\
\hline Megaselia brejchaorum ${ }^{\wedge}$ L.A. & 11 \\
\hline
\end{tabular}

Table 2 (continued)

Megaselia scutellaris $* \wedge$

Megaselia friedrichae $\wedge^{\wedge \text { L.A. }}$

Megaselia cavifemur $^{\wedge}$

Conicera aldrich $i^{\wedge}$

Aenigmatias sp. ${ }^{\wedge}$

Megaselia baileyae $\wedge^{\wedge \text { L.A. }}$

Phora aerea $^{\wedge}$

Pseudacteon californiensis ${ }^{\wedge}$

Megaselia losangelensis $\wedge$ L.A.

Megaselia globipyga ${ }^{\wedge}$

Triphleba sp. $\wedge$

Megaselia joanneae $\wedge^{\wedge \text { L.A. }}$

Megaselia gonzalezorum $^{\wedge}$ L.A.

Megaselia glabrifrons

Apocephalus aquilonius $\wedge$

Pseudacteon crawfordi ${ }^{\wedge}$

Beckerina sp. $2^{\wedge}$

Megaselia hoffmanorum $\wedge^{\wedge \text { L.A. }}$

Megaselia pongsaiae $\wedge^{\wedge \text { L.A. }}$

Veruanus boreotis ${ }^{\wedge}$

Megaselia phyllissunae $\wedge^{\wedge \text { L.A. }}$

Pseudacteon onyx ${ }^{\wedge}$

Metopina group

Megaselia shatesae $^{\wedge \text { L.A. }}$

Phora coangustata ${ }^{\wedge}$

Gymnophora talea ${ }^{\wedge}$

Megaselia seaverorum $\wedge$ L.A.

Megaselia stoakesi ${ }^{\wedge}$ L.A.

Myriophora alexandrae ${ }^{\wedge}$

Megaselia studentorum $\wedge^{\wedge}$ L.A.

Phora cristipes $\wedge$

Megaselia voluntariorum $^{\wedge}{ }^{\wedge}$ L.A.

Megaselia bradyi^ L.A.

Apocephalus sp. Female ${ }^{\wedge}$

Megaselia risoria $\wedge^{\wedge \text { L.A. }}$

each site is represented by both the size and color of the marker sphere. The percentage of Megaselia agarici ranged from about $4 \%$ of the catch (site 5) to $75 \%$ of the catch (site \#21) (Figs. 6 and 7). Sites with larger numbers of specimens had more species (Fig. 8), possibly indicating the shared requirements of much of the fauna.

Pooled monthly catches strongly peaked in May, led by Megaselia agarici and the three next most abundant species

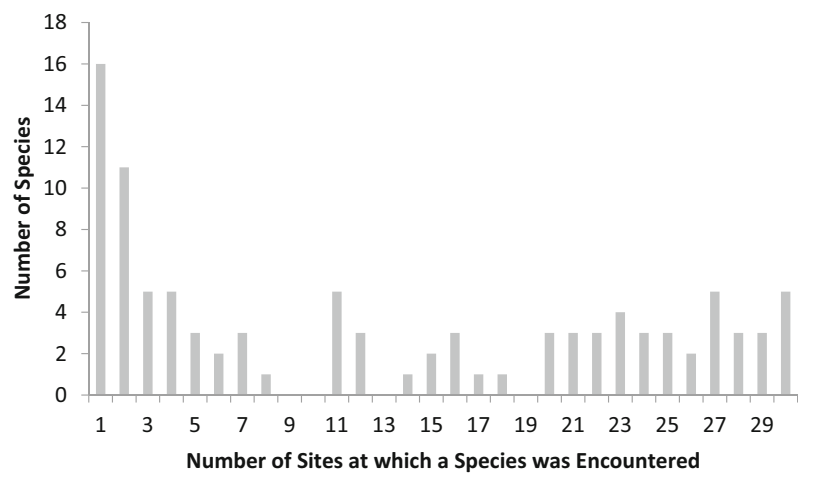

Fig. 4 Frequency histogram of number of sites per phorid fly species 


\begin{tabular}{ll} 
Table 3 Number of & \\
species per site (as Site \# & $1-36$ \\
- number of species) & $3-43$ \\
& $4-48$ \\
$5-43$ \\
$6-52$ \\
$7-50$ \\
$8-19$ \\
$9-30$ \\
$10-23$ \\
$11-41$ \\
$12-46$ \\
$13-82$ \\
$14-47$ \\
$15-32$ \\
$16-47$ \\
$17-42$ \\
$18-40$ \\
$19-45$ \\
$20-32$ \\
$21-25$ \\
$22-39$ \\
$23-43$ \\
$24-46$ \\
$25-44$ \\
$26-36$ \\
$27-35$ \\
$28-55$ \\
$29-45$ \\
$30-58$ \\
$31-59$ \\
\hline
\end{tabular}

(Fig. 9). Total catch for May was about 7000 specimens, 18\% of the entire year's total. Some species peaked earlier or later, and some were found almost exclusively during the (extremely mild, even by southern California standards) winter.

Some species, including $M$. agarici, appeared to show two strong peaks during the year. Examination of the catches from individual sites, however, shows that this pattern is an artifact of pooling data. For example, M. agarici abundance at some sites (especially 16, 18, 23) had a strong peak in May, and others (3, 8, 9, 12, $17,19)$ peaked in November. Individual sites do not often show strong peaks in both months, although many do have higher numbers in those parts of the year when compared to the surrounding months. It is unknown if this type of pattern is an indication of a bivoltine biology that is expressed differently in different microhabitats/climates. The other likely explanation, supported by the patterns seen by Disney et al. (1981), is that the severe drought in California has caused lower numbers during the hot, dry, summer months. Thus, the higher numbers that should last throughout the summer instead appear as some form of dual peaks before and after the hottest part of the year. As California is still very much in drought, we cannot yet examine this phenomenon. If (when) the drought situation changes it will be interesting to see how this affects phenology data.

Besides the relatively constant domination of samples by Megaselia agarici and others, we noted significant "outbursts" of some species. Most significant were 459 M. marquezi from site 5 during April and 470 M. barberi from site 26 during March-April; unfortunately, neither has a known lifestyle.

In addition to the main BioSCAN transect, several Malaise traps have been used to do supplemental collection in select locations. Although these results are somewhat limited, they did offer some interesting data, below.

City Hall: In July and August of 2015, we erected three Malaise traps around Los Angeles City Hall. The locations were at ground level on the north side of City Hall, a canopy trap suspended in the palm trees south of the west entrance to City Hall, and on the roof of City Hall South. In total, 11 species were found from these traps, the roof trap ( 8 stories up) collected only 4 species. The low diversity of the samples was not surprising given the downtown (heavily urbanized) location of City Hall. What was surprising was that every sample collected from City Hall (from all three traps, all weeks) was dominated by our local Metopina species, a result not seen at any other BioSCAN site. Prescher and Büchs (1997) recorded Metopina dominating (between 50.5$72.9 \%$ ) the fauna of wheat, corn and potato fields in Germany. Similarly, Froese (1992) found that $79.7 \%$ of the phorids obtained from the soils of arable fields in Germany were Metopina. Since the genus does not appear to be associated with a particular crop, it may be associated with freshly turned soil. The grounds of City Hall were recently landscaped, and an adjacent lot was being developed, offering an explanation for the dominance of this genus in these Malaise traps. A second interesting find from City Hall was that in late August the trap on the north side at ground level caught a single specimen of Megaselia seticauda Borgmeier. This species, known to be a pest of corn, was not found elsewhere in our BioSCAN sampling. We have no explanation for this oddity, but here include it to show the value of supplemental collection - you never know what one additional trap, or week of collection, will reveal!

Angel City Brewery: We collaborated with a local brewery to place a Malaise trap on their roof in Downtown Los Angeles in spring 2016 for six weeks (March 1 - April 14). The roof is home to a garden that includes hops for their brewing and an assortment of fruits and vegetables. The samples we got from this roof (3 stories up, approximately $1 / 2$ mile from our trapping at City Hall and in a similarly urbanized part of L.A.) were 
Fig. 5 Visualization of biodiversity for BioSCAN sites. The size and color (blue $=$ low diversity to red $=$ high diversity) of the spheres is representative of the biodiversity found at that site

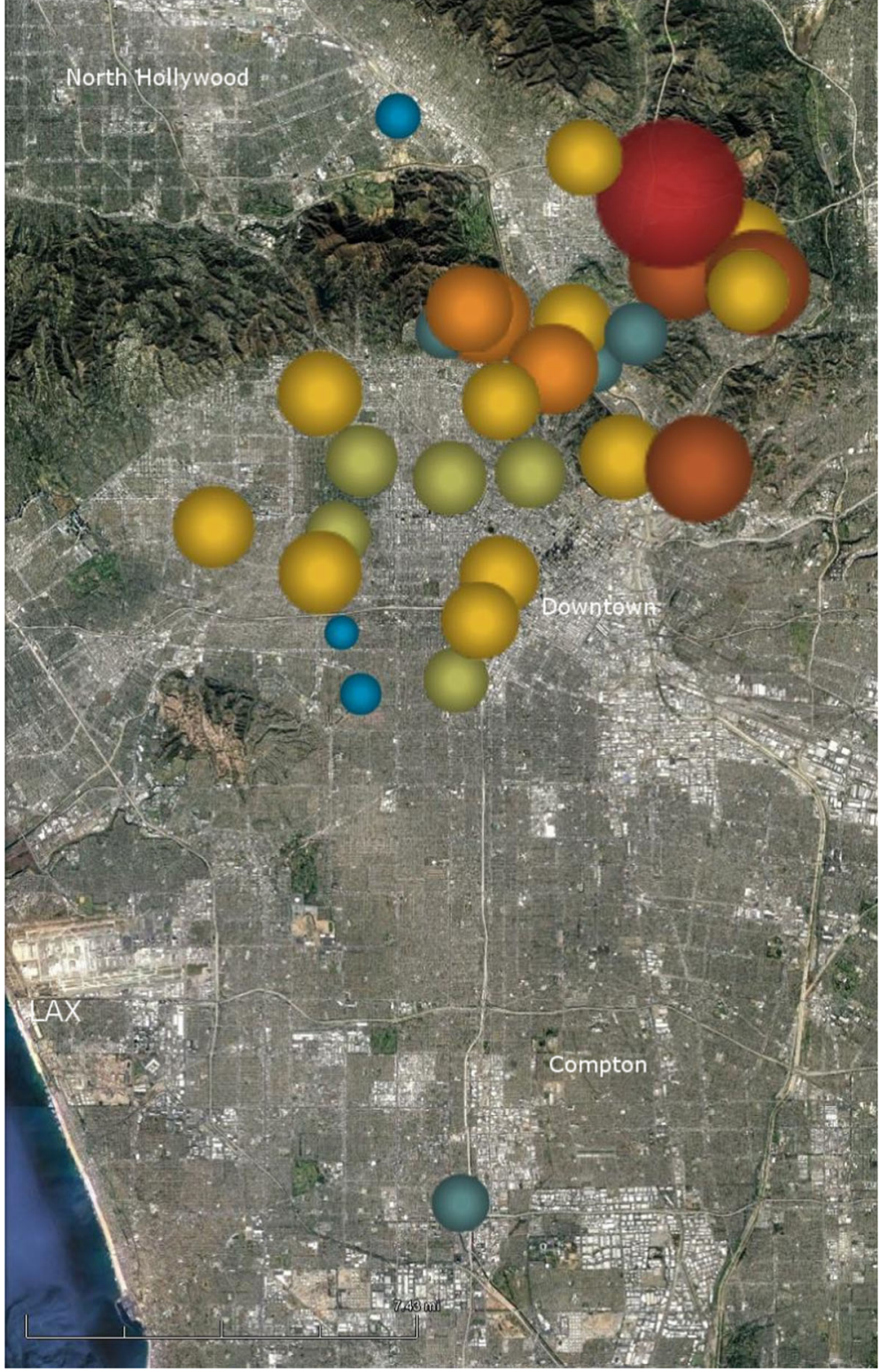

dominated by $M$. agarici, with that species being approximately $65 \%$ of the total collection. A total of 13 species were found on this roof. With future sampling, we hope to discover how much a rooftop garden (or other green space) contributes to biodiversity.

US Bank Tower: We placed a trap on the roof of the tallest building west of the Mississippi, the US Bank Tower, in late September 2015. Trapping was ongoing for two months (24 September - 29 October). Specimen numbers this high (over $1000 \mathrm{ft}$, just below the helipad) were extremely low. Half of the weekly samples contained no phorids at all, and the ones that did, contained only 2 or 3 phorid specimens. Only two species, M. agarici and M. lombardorum, were found. It is unknown if these flies were actually flying at this height or were, perhaps, blown up to the roof. Both are common L.A. species, and numbers were not sufficient to make any conclusive statements about the composition of the fauna at this altitude.

\section{Diversity data}

A species accumulation curve for the pooled 360 samples is given in Fig. 10. Based on various estimators, the entire fauna is almost fully sampled, and should total between 101 and 106 species (Table 4).

Individual traps collected from 105 phorid specimens (site 8) to 3505 phorids (trap 28, Fig. 6). The catch from trap 8 is suspect, however, because in October, 2014, a crack was found in the plastic collecting head, through which many phorids might have escaped. Similarly, sites 9 and 10 had 
Fig. 6 Catch per site, arranged from most "species-rich" (on left) to least species-rich (on right); each color representing a species. Red = Megaselia agarici

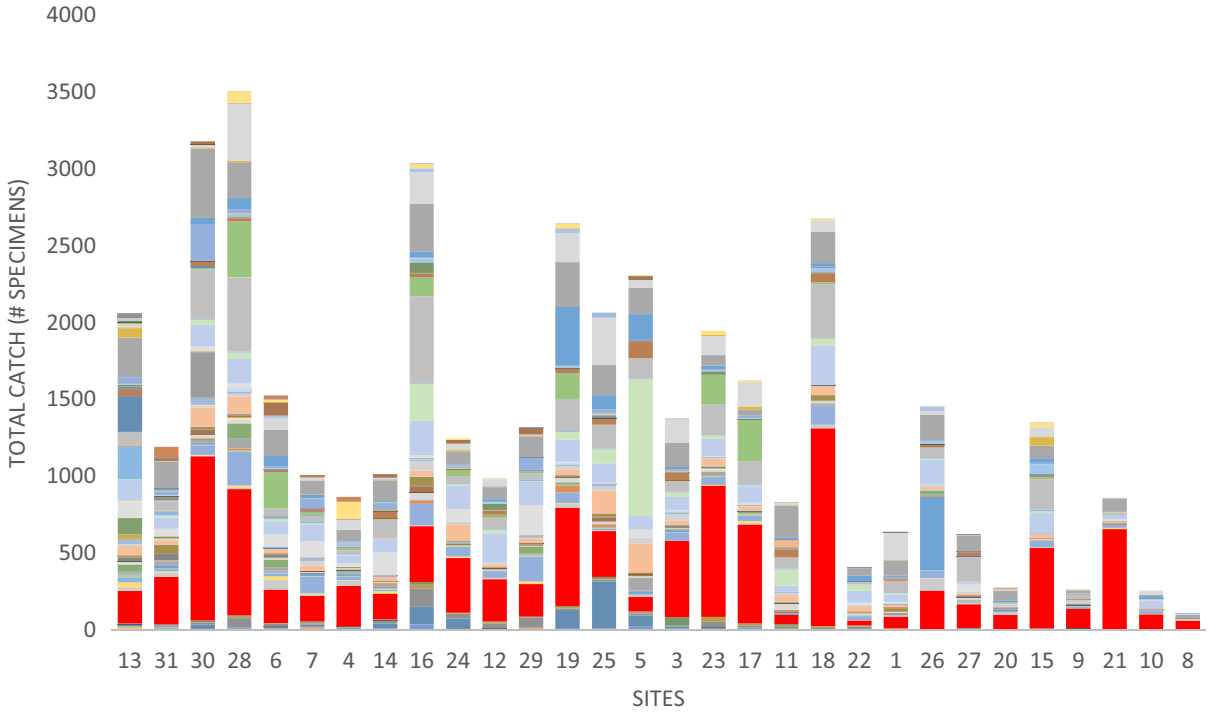

some months with no phorid catch, which seemed to us unlikely, but we have no evidence that there were any factors negatively affecting the sampling.

Four diversity statistics are calculated by Estimates, which, aside from ranking site 13 highest and site 21 lowest, gave similar results (Table 5), although differing in some details.

Analysis of mean number of species per trap showed significant diversity within sites (Table 5), but pairwise t-tests found that only some sites differed significantly from others (Fig. 12).

\section{Discussion}

Our study is possibly the largest and most complete inventory of an urban fly fauna ever attempted (other similar projects include Avondet et al. 2003, Centeno et al. 2004, Castrezana et al. 2010). Detailed knowledge of a complete fauna allows us to study changes, such as population fluctuations, establishment and spread of invasive species, and extirpation of existing species.

Based on our work, the phorid fauna of the sampled area of Los Angeles is about 100 species, and estimated to include only a few more species than we have already found. Distribution throughout the city is largely homogenous, but sites closer to natural areas (mostly found in hills and mountains) have higher species richness.

There are few, if any, historical collections of phorids from urban Los Angeles for comparison to our results. At the Los Angeles County Museum of Natural History (LACM), material predating Brown's arrival in 1993 consists of scattered specimens of Megaselia agarici, M. scalaris, M. sulphurizona, and a few Phora specimens, all of which date back only to the $1950 \mathrm{~s}$. We cannot exclude the possibility that there exists somewhere a more substantial holding of
Fig. 7 Species catch as percentage of total catch per site; sites arranged from most speciesrich (on left) to least species rich (on right). Red = Megaselia agarici

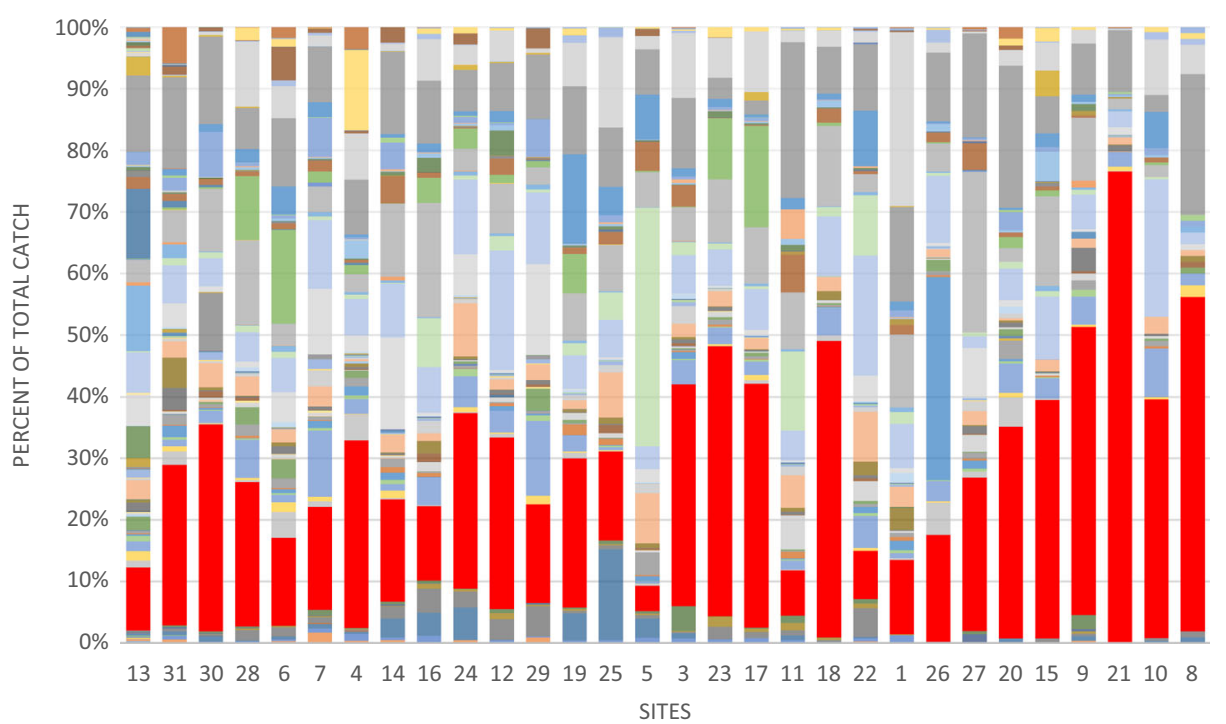




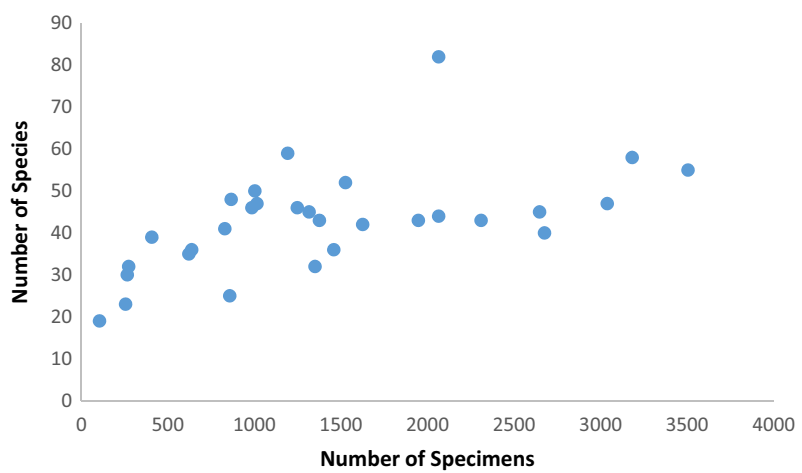

Fig. 8 Number of species versus number of specimens per site

phorids from Los Angeles tucked away in a collection somewhere, but the paucity of the LACM in this regard seems to make this unlikely. Without historic collections, little can be determined about the changes that have occurred within the fauna over time. Rather, our data provides a much needed baseline for future studies of this type.

Life histories and distribution of most phorid species are unknown, with some exceptions. Species found in Europe and North America are presumed to be introductions through commerce, some possibly dating back a few centuries (Lindroth 1957). These recent introductions may have gone either direction, or may be from another geographic region entirely (but have simply not been recorded from their region of origin as of yet). The dominant species in our survey, Megaselia agarici, was originally described (as Phora agarici) from specimens reared from commercially grown Agaricus in New York in 1894 (Lintner 1895). It is not known whether this species was introduced from the eastern USA into California, or whether it is a native species across the country.

A summary of the known lifestyles (from Disney 1994; subsequent papers are cited individually) is as follows, all referring to larval feeding:

Fungivory (some scavengers will feed on fungi as well): This was by far the dominant known lifestyle, representing at least $40 \%$ of specimens collected. Megaselia agarici, $M$. halterata, and M. nigra all feed exclusively (or nearly so Disney 2006b) on Agaricus, with M. nigra feeding on the fruiting body and $M$. halterata feeding on the mycelium. Other fungus feeding Megaselia in our list are M. berndseni, which has been reared from a wide variety of fungi, and M. scutellaris, with records from Agaricus and some other genera (Disney 2006b). The worldwide Chonocephalus bentacaisei has been reared from unidentified fungi from Madagascar (Paulian 1958), the only known breeding record for this species. All of the fungivores are potentially introduced species that occur elsewhere in the world.

Scavengers in rodent burrows: This includes a single native species, the largest phorid found in the survey: Anevrina variabilis.

Scavengers on buried carrion: The species of Conicera includes the famous coffin fly, $C$. tibialis, which is a wellknown breeder in buried corpses. Sharing this habit is C. similis (García-Rojo et al. 2013, Karapazarlioglu and Disney 2015). Much less information exists for the other species of this genus found in our study, Conicera aldrichi; it is probable they have similar habits (Buck 1994). The species of Triphleba collected in our study might also belong here.

Aquatic phorids: Although there are few known species (Disney 1991), we collected one of those phorids, Megaselia hansonix, known to have aquatic larvae. There are few ponds or waterways in which these flies can breed in Los Angeles, but there are many abandoned swimming pools and overirrigated sites in which they could develop.

Parasitoids: Parasitoids of ants. Aenigmatias sp., Apocephalus spp., Microselia sp., Pseudacteon spp., Veruanus boreotis. Parasitoids of millipedes. Myriophora alexandrae. Kleptoparasitoids of halictid bees. Phalacrotophora halictorum.

General scavengers: These are the best known phorids, which often turn up in households or human products: Dohrniphora cornuta, Megaselia pleuralis, M. ruficornis, M. rufipes, M. scalaris, Puliciphora virginiensis, Spiniphora bergenstammii.
Fig. 9 Phenology of all species at all sites. Each line represents a species; topmost line is Megaselia agarici

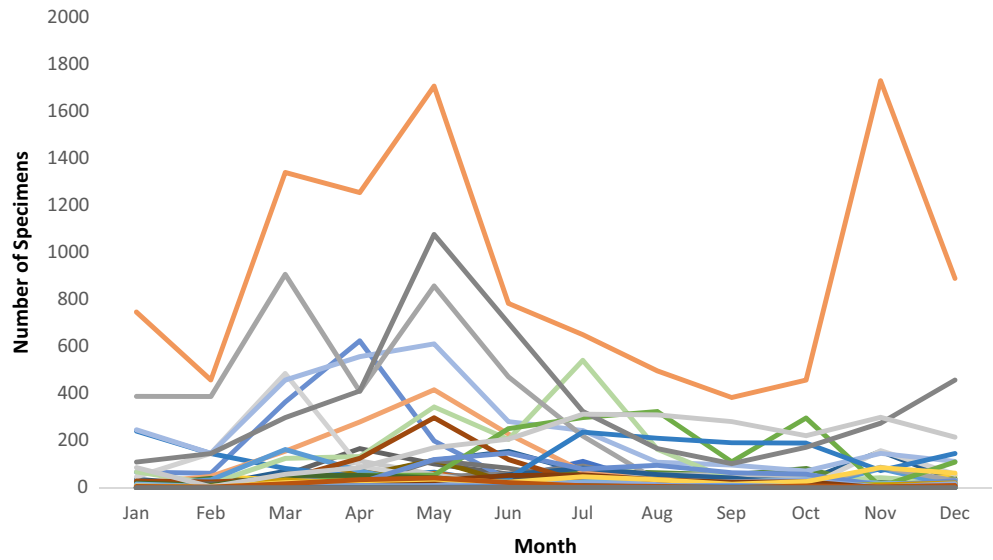


Fig. 10 Species accumulation curve of 360 pooled Malaise trap samples

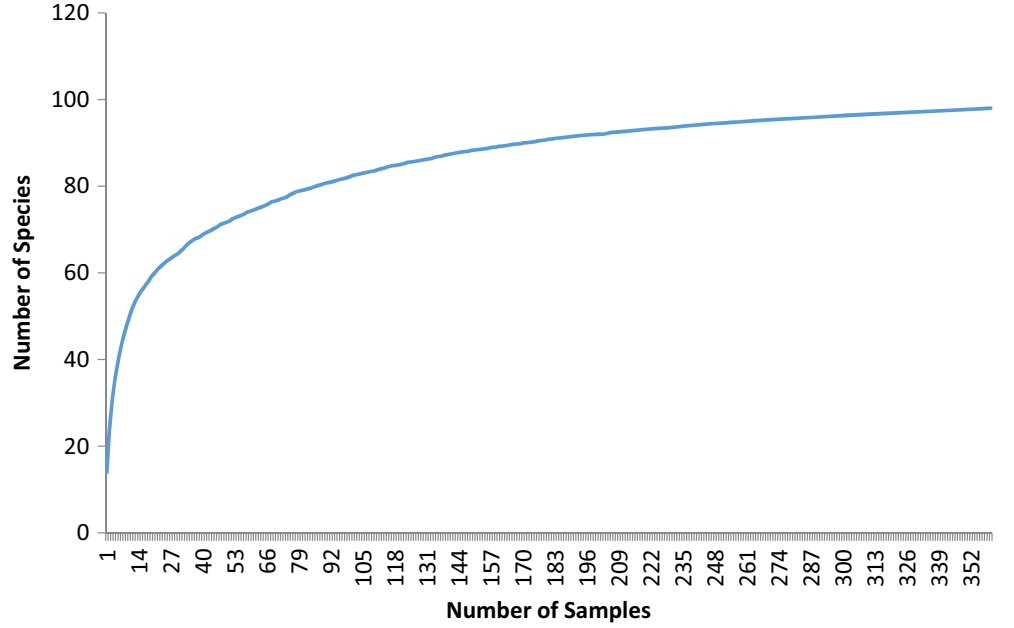

Dead invertebrate scavengers: Presumably there are others, but we only classify Diplonevra setigera and Gymnophora talea in this group (both based on other species in their genera).

\section{Among site comparisons}

The most diverse site was site \#13 (Figs. 2, at bottom, and 11), which is virtually natural backyard habitat in the Verdugo Mountains. The total for this site, 82 species, is remarkably higher than that for the second richest site, \#31, with 59 species. The 23 species absent from site \#31, but present in site $\# 13$, are mostly rarely encountered species shared with only one other site. Most species known from only one or two sites were found at site \#13, including Gymnophora talea, Aenigmatias sp., and most of the ant-parasitoid species in the genera Apocephalus, Microselia, Pseudacton, and Veruanus. The restriction of ant-parasitoids to the least disturbed sites is undoubtedly due to the presence of the Argentine ant, Linepithema humile, in the more central, urbanized part of the L.A. basin. This introduced species is found almost everywhere, especially where soil has been disturbed and irrigation exists. It outcompetes native ants, rendering most of Los Angeles free of native species, as well as their commensals, parasitoids, and predators. It is unknown

Table 4 Estimated species richness based on analysis using EstimateS (Colwell 1997)

\begin{tabular}{ll}
\hline ACE & 102.12 \\
\hline ICE & 102.70 \\
Chao 1 & 103.60 \\
Chao 2 & 101.10 \\
Jack 1 & 105.98 \\
Jack 2 & 106.00 \\
Bootstrap & 102.53 \\
\hline
\end{tabular}

whether the presence of Argentine ants is responsible for the elimination of other phorids in more urbanized areas, but it does not seem impossible. A big step towards restoring Los Angeles biodiversity would be the eradication of this synanthropic ant, which is unfortunately unlikely, given its ubiquity and apparent ecological dominance. Study and importation of phorid flies in South America known to attack Argentine ants might offer some relief for native species.

Interestingly, two cosmopolitan species of phorids, Megaselia scalaris (Fig. 11) and Conicera tibialis (the "coffin fly") (Fig. 11) were not collected at site \#13 or site \#31, indicating that these species might be true synanthropes, needing to live in close association with humans. Disney (2008) reviewed the natural history of Megaselia scalaris and listed, among its larval foods, paint and shoe polish (among more normal sources of nourishment like carrion, fungi, bacteria, and other insects), hinting at the incredible adaptability of this species. Another species that appeared to have a strictly urban distribution was M. ilca (Fig. 11), a North American species. Fascinatingly, we have discovered M. ilca in samples from natural habitat in the mountains on the perimeter of the Los Angeles Basin. We are curious what set of conditions has led to the bipolar situation for this species.

The least species-rich sites were 8 and 10, although data from site 8 cannot be used confidently (as mentioned above). All diversity statistics ranked site 21 as least diverse, probably because of the overwhelming dominance by Megaselia agarici. Dominance of this species was highly negatively correlated with overall species diversity per site. Its occurrence was most highly correlated $(0.63)$ with that of the introduced fungus feeder, Megaselia nigra. Another major fungus feeder, Megaselia halterata, had a much lower correlation (0.25), perhaps due to its dependence on the mycelium of fungi rather than the fruiting bodies (Fig. 12.)

The usual urban biodiversity paradigm is to classify species as urban avoiders, urban exploiters, and intermediate urban 
Table 5 Diversity statistics for sites, ordered arbitarily on ranking based on Fisher's Alpha (highest to lowest)

\begin{tabular}{|c|c|c|c|c|}
\hline Site & Fisher's Alpha & Shannon & Exponential Shannon & Simpson (inverse) \\
\hline 13 & 16.82 & 3.21 & 24.7 & 15.16 \\
\hline 31 & 13.03 & 2.89 & 17.93 & 9.18 \\
\hline 7 & 11.07 & 2.93 & 18.78 & 12.16 \\
\hline 4 & 10.95 & 2.64 & 14.02 & 7.44 \\
\hline 22 & 10.62 & 2.79 & 16.22 & 11.13 \\
\hline 6 & 10.41 & 3.01 & 20.27 & 13.21 \\
\hline 14 & 10.2 & 2.75 & 15.72 & 10.28 \\
\hline 30 & 10.07 & 2.42 & 11.24 & 6.15 \\
\hline 12 & 10 & 2.57 & 13.09 & 7.28 \\
\hline 20 & 9.41 & 2.35 & 10.47 & 5.45 \\
\hline 24 & 9.4 & 2.67 & 14.39 & 8.13 \\
\hline 28 & 9.26 & 2.68 & 14.62 & 9.08 \\
\hline 11 & 9.06 & 2.69 & 14.72 & 9.01 \\
\hline 29 & 9.02 & 2.68 & 14.6 & 10.27 \\
\hline 9 & 8.7 & 2.17 & 8.72 & 4.07 \\
\hline 3 & 8.43 & 2.44 & 11.53 & 5.95 \\
\hline 1 & 8.26 & 2.44 & 11.48 & 7.06 \\
\hline 27 & 8.02 & 2.24 & 9.35 & 5.88 \\
\hline 25 & 7.9 & 2.72 & 15.13 & 10.65 \\
\hline 16 & 7.89 & 2.85 & 17.29 & 11.75 \\
\hline 17 & 7.87 & 2.16 & 8.68 & 4.78 \\
\hline 23 & 7.78 & 2.19 & 8.96 & 4.44 \\
\hline 19 & 7.7 & 2.63 & 13.83 & 8.76 \\
\hline 5 & 7.5 & 2.4 & 10.99 & 5.58 \\
\hline 8 & 6.78 & 1.62 & 5.04 & 2.85 \\
\hline 26 & 6.68 & 2.25 & 9.51 & 5.86 \\
\hline 18 & 6.67 & 1.95 & 7.03 & 3.72 \\
\hline 10 & 6.13 & 2 & 7.36 & 4.53 \\
\hline 15 & 5.88 & 2.22 & 9.17 & 5.16 \\
\hline 21 & 4.82 & 1.05 & 2.86 & 1.68 \\
\hline
\end{tabular}

toleraters (e.g., McKinney 2002). For our data, 40 species were urban avoiders (Table 2), many of them found only at site \#13 (the species in the top row, towards the right in Fig. 11). This list includes nearly all of the non-Megaselia genera, except for the introduced synanthrope Dohrniphora cornuta, and a few others. An example of an urban avoider's range is Anevrina variabilis, which is apparently unable to live without populations of wild rodents in close proximity (Fig. 13).

Urban exploiters include Megaselia agarici and other common fungus feeding species, which seem to benefit greatly from the apparent increased presence of Agaricus mushrooms in urban settings. The qualifier "apparent" is used in the previous sentence because we have found no surveys of urban fungi that we can cite. Wherever Agaricus mushrooms occur, however, they can have a profound effect on the phorid fauna, as we have found over one-hundred larvae in a single fruiting body of these fungi (unpublished data).
Origins of the fauna are difficult to ascertain. We assume that any species with a joint New World-Europe distribution may have been introduced into North America, or vice versa (often these species are also found elsewhere in the world). By this criterion, at least 18 out of 99 species are potentially introduced to Los Angeles. Many species are described for the first time in this study, and consequently are not yet known from any other parts of the world. Undoubtedly, however, some of these species will be found to have originated in parts of the world other than the relatively well studied parts of Europe, as have some of the other accidentally introduced species that our study has discovered (Grimaldi et al. 2015).

\section{Comparison with other nearby sites}

Finding sites that are strictly comparable to ours is difficult. Most of the original habitat in the lower parts of 


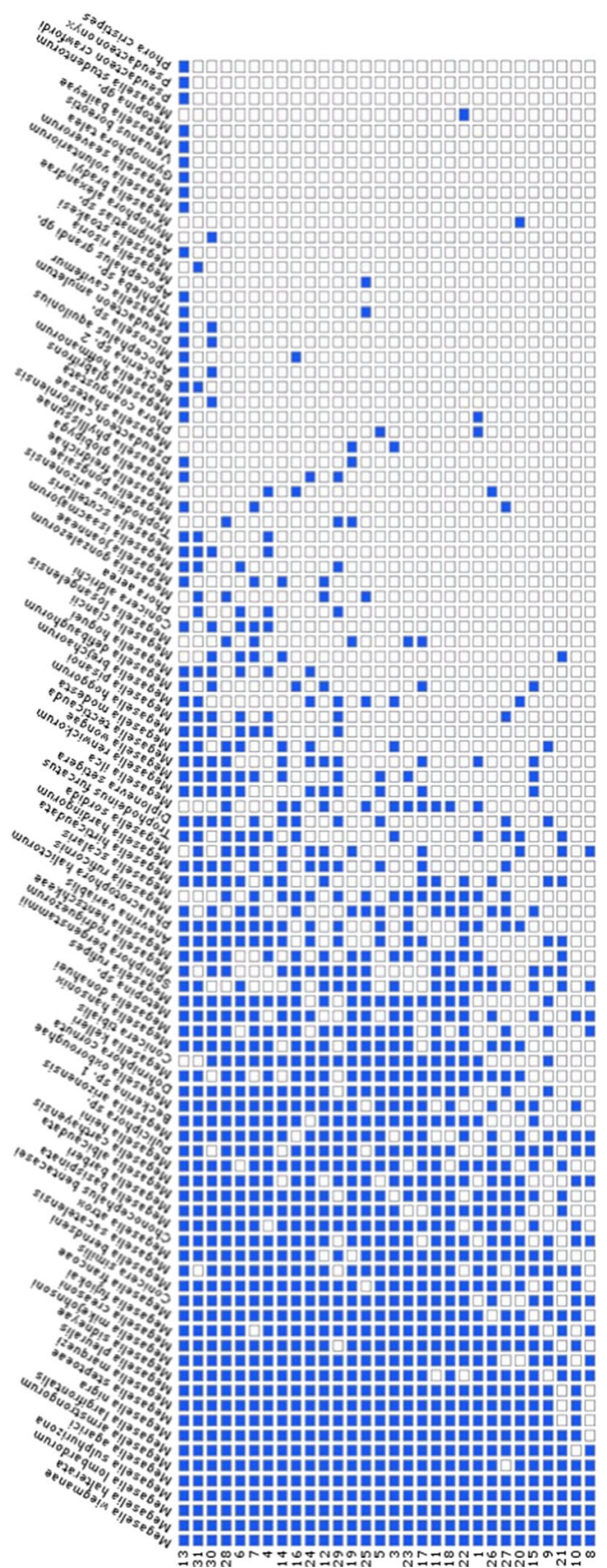

Fig. 11 Presence-absence matrix. Rows: top to bottom, most diverse to least diverse site. Columns, most widespread to least widespread species, left to right

the basin is either converted to residential land or highly degraded by human activity. Thus, we are forced to compare with higher elevation sites in the nearby mountains. Compared with the few samples that we have so far analyzed from more natural areas surrounding Los Angeles, our catches are strongly differentiated from those at the more natural sites. In a sample from Diamond-X Ranch in the nearby Santa Monica
Mountains (34.098 N 118.699 W, 215 m), Megaselia agarici comprised only 4\% (9/209) of the phorid sample, which was otherwise dominated by dozens of other Megaselia species.

\section{Comparison with other urban sites}

Durska (1981) reported on an urban survey in Warsaw, Poland, in which three types of sites were sampled: parks, housing estates, and the town center. This study predated her more intensive work on phorid flies, and includes only 1066 specimens belonging to 36 species. Their collecting technique was also highly divergent from ours, being a type of pan trap in the crowns of trees. Nevertheless, they found that species abundance and richness decreased from parks to housing estates and again from housing estates to the town center. Their most dominant species overall was Megaselia angusta, an Old World species not found in our survey and belonging to a difficult complex of species that are prone to misidentification (Disney 1999). The highest level of domination by this species was $33.3 \%$ in the samples from parks. Other dominant species were Diplonevra nitidula, Megaselia "pulicaria" (the species after which the aforementioned complex of species that includes $M$. angusta is named), Megaselia rufipes, and Phalacrotophora fasciata; of these, only M. rufipes was also found in our survey at relatively low levels. From their total list, the only other species shared with our project was Dohrniphora cornuta.

Durska $(2001,2002)$ also studied the fauna of successional growth in (non-urban) pine forests, and presented both pooled and individual species phenology charts for a site in Poland. Overall, her charts resembled patterns seen in Los Angeles for Megaselia agarici in L.A. (Fig. 9), with a large post-autumnal rise in abundance. Other phorids in our study did not show such a prominent late surge. Also, our data had its largest peak in May, whereas the pooled data in Durska's study peaked in October. These discrepancies may be due to the geographical position of Los Angeles being much farther south than Warsaw, the previously discussed drought in California, or a combination of the two.

The list of phorids found in Malaise trapping in the Buckingham Palace garden in England (Disney 2001) included a number of species that are widely recorded, including in Los Angeles. Ten species were found in common with Los Angeles: Conicera similis, Dohrniphora cornuta, Megaselia albicaudata, M. basispinata, M. berndseni, M. nigra, M. pleuralis, M. ruficornis, M. rufipes and Spiniphora begenstammi. A similar faunal list from Henry Disney's decades of multi-method trapping in Cambridge, UK (mostly in his backyard) can be 
Fig. 12 Pairwise mean species richness per site comparisons. White boxes - no significant differences; yellow boxes - rowlabeled site significantly lower than column labeled site (e. g., site 1 vs site 6 ); green boxes row-labeled site significantly higher than column labeled site $\begin{array}{lllllllllllllllllllllllllllll}3 & 4 & 5 & 6 & 7 & 8 & 9 & 10 & 11 & 12 & 13 & 14 & 15 & 16 & 17 & 18 & 19 & 20 & 21 & 22 & 23 & 24 & 25 & 26 & 27 & 28 & 29 & 30 & 31\end{array}$

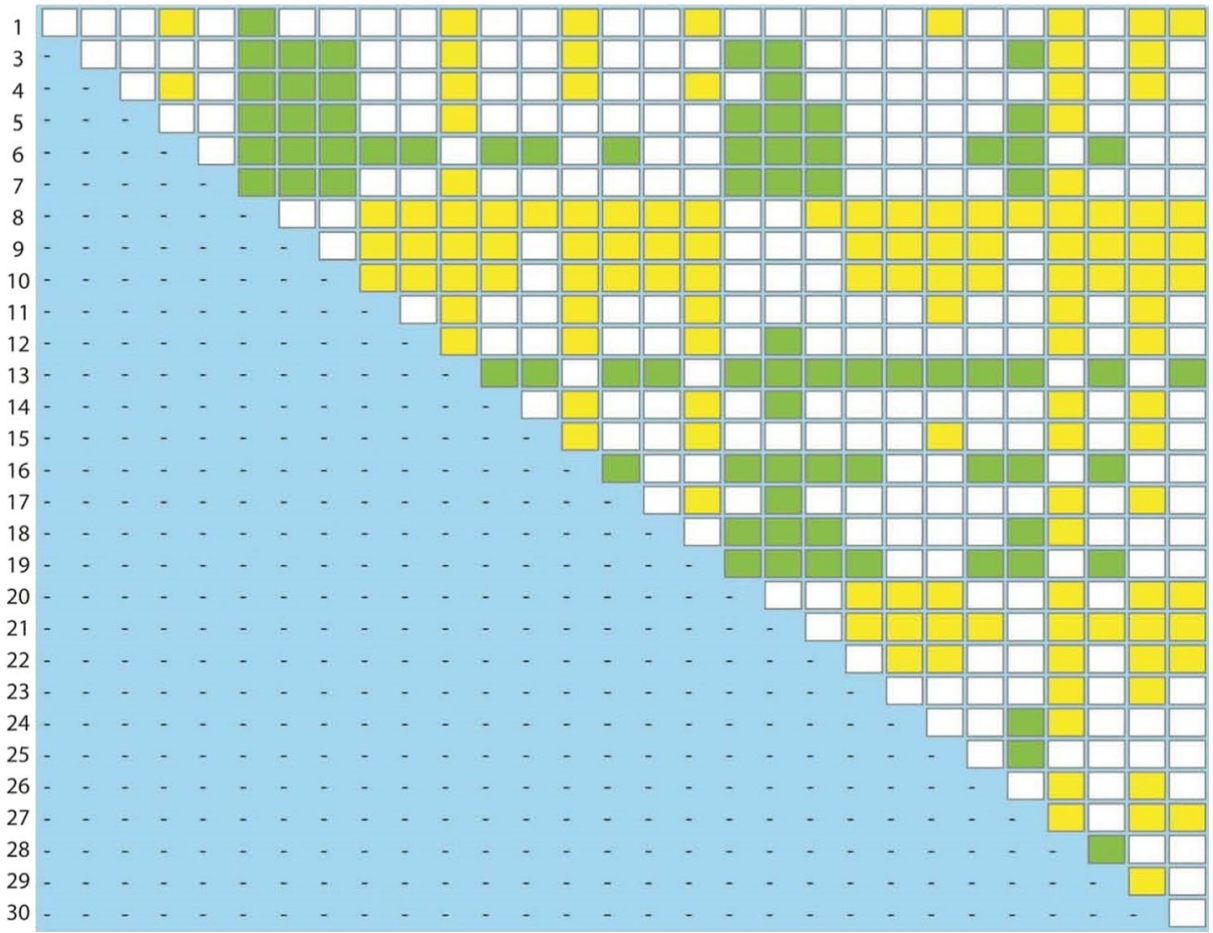

found in Table 6 (R.H.L. Disney, Personal Communication, May 24, 2016). This list shares nine of the same species with Los Angeles as the garden at Buckingham Palace (the Cambridge list also includes M. halterata but omits M. pleuralis). Interestingly, Disney's observations on those species that will, at least on occasion, dominate sampling efforts did not include any of the overlap species we see in large numbers in Los Angeles (such as M. nigra). The dominating species in Cambridge did

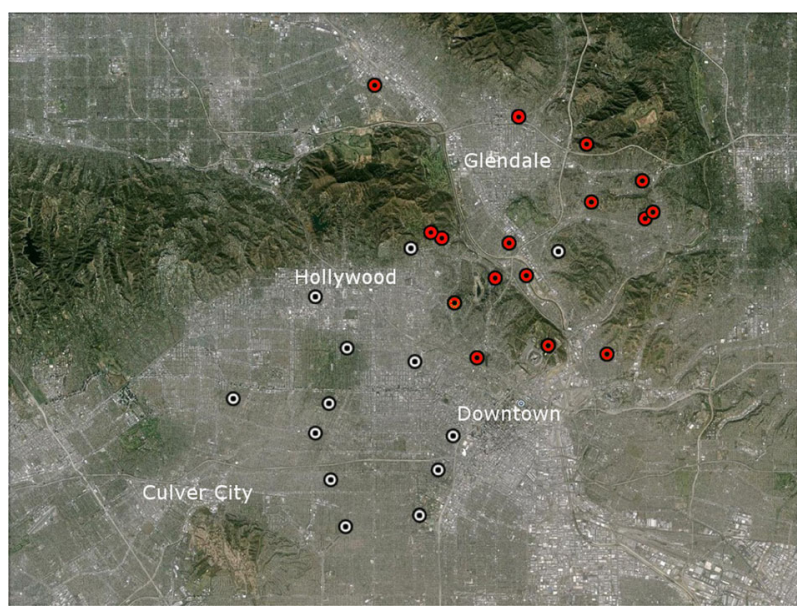

Fig. 13 Distribution of Anevrina variabilis (red markers) among 29 of the 30 BioSCAN sites (Site \#15 omitted) include two species (M. bendseni and M. rufipes) that we see (but in relatively low numbers) in Los Angeles.

We can find no record of any other faunal list dominated by Megaselia agarici like the Angeleno fauna. This is likely due to the fact that no other faunal lists exist for any urban (or natural) sites in North America.

\section{Summary}

This study lays the foundation for ecological analysis and future studies on urban phorid biodiversity. The phorid fly fauna of Los Angeles dramatically reveals, even with preliminary level analysis, the erosion of biodiversity due to anthropogenic change. The striking visual representation of this phenomenon is shown in Fig. 11, where over one-half of the boxes are white (species not recorded at that location), and even many of the filled boxes represent introduced, or potentially introduced, species. The goal for conservation biology is to fill as many of these boxes as possible, to increase biodiversity using what we discover about factors that influence species loss, based on these data. Although such small, obscure flies may seem unlikely candidates to inspire political action, they are representative of the large majority of biodiversity that is small, poorly-known, yet vitally important. 
Table 6 Phoridae recorded from Henry Disney's suburban backyard in Cambridge, UK with several additional species found in other gardens and parks in Cambridge

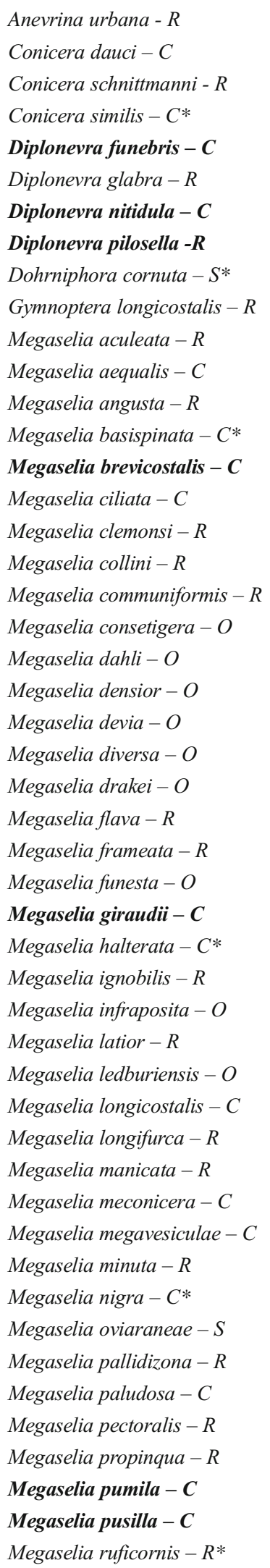

Table 6 (continued)

Megaselia rufipes - $C$

Megaselia stichata $-R$

Megaselia stigmatica - $O$

Megaselia subfuscipes $-R$

Megaselia subnudipennis - $C$

Megaselia sylvatica - $O$

Megaselia tarsalis $-R$

Megaselia tumida $-R$

Metopina galeata $-R$

Metopina oligoneura - C

Metopina perpusilla $-R$

Metopina pileata $-R$

Metopina ulrichi- $R$

Phalcrotophora fasciata $-R$

Phora atra - C

Phora holosericea $-R$

Phora tincta - C

Pseudacteon formicarum $-R$

Spiniphora bergenstammi $-C^{*}$

Spiniphora maculata $-R$

Triphleba autumnalis $-R$

Triphleba distinguenda-C

Triphleba intermedia $-R$

Triphleba lugubris $-C$

Triphleba nudipalpis - C

$B$. other gardens and parks

Conicera floricola $-R$

Megaselia albicaudata $-R^{*}$

Megaselia berndseni-C*

Megaselia flavicans $-R$

Megaselia involuta $-R$

Megaselia lactipennis $-R$

Megaselia nigriceps $-R$

Megaselia plurispinulosa -O

Megaselia spinata - $O$

Megaselia verralli - $O$

Phalcrotophora berolinensis $-R$

$\mathrm{C}=$ common $. \mathrm{R}=$ regular. $\mathrm{O}=$ occasional, $\mathrm{S}=$ scarce

Species in bold have been found, at times, to dominate a catch

Species with an asterisk $(*)$ were also recorded from BioSCAN

Acknowledgements The authors thank the BioSCAN team for working tirelessly on every aspect of this project. This gratitude extends to current and former staff, students, site hosts, and volunteers. This project takes an army, and they are an incredible one. In particular, we thank Lisa Gonzalez, Estella Hernandez, and Kelsey Bailey. We thank Henry Disney for assisting in the identification of our phorids, and for allowing us use of his own backyard phorid list. Our supplemental sampling could not have been done without the help of key individuals and companies. At City Hall, Deborah Deets, Councilmember Paul Koretz, and Andy Shrader dedicated their time and energy to getting us access to sample at this historic Los Angeles landmark. Overseas Union Enterprise, the ownership group of the US Bank Tower, is thanked for permission to utilize their roof as a study site. The fabulous team at Angel City Brewery is thanked for collaborating on rooftop trapping and public engagement with our research. The Seaver Institute and Western Exterminator are thanked as sponsors. BioSCAN is generously funded by the Natural History Museum of Los Angeles County. Dr. Gail Langellotto and a second anonymous reviewer are thanked for feedback on this manuscript. This is publication number 12 of the BioSCAN Project. 
Open Access This article is distributed under the terms of the Creative Commons Attribution 4.0 International License (http:// creativecommons.org/licenses/by/4.0/), which permits unrestricted use, distribution, and reproduction in any medium, provided you give appropriate credit to the original author(s) and the source, provide a link to the Creative Commons license, and indicate if changes were made.

\section{References}

Avondet JL, Blair RB, Berg DJ, Ebbert MA (2003) Drosophila (Diptera: Drosophilidae) response to changes in ecological parameters across an urban gradient. Environ Entomol 32:347-358

Bragança MAL, Souza LM, Nogueira CA, Della Lucia TMC (2008) Parasitism by Neodohrniphora spp. Malloch (Diptera, Phoridae) on workers of Atta sexdens rubropilosa Forel (hymenoptera, Formicidae). Revista brasileira de Entomologia 52:300-302

Brown BV (1993) A further chemical alternative to critical-point-drying for preparing small (or large) flies. Fly Times 11:10

Brown BV, Borkent A, Wetzer R, Pentcheff D (2014) New types of inventories at the Natural History Museum of Los Angeles County. Am Entomol 60:231-234

Buck M (1994) Community structure and niche partitioning of Diptera breeding in small-sized and buried carrion (Phoridae, Sphaeroceridae). General submitted paper at 3rd International Congress of Dipterology: 8 pp.

Castrezana S, Faircloth B, Gowaty P (2010) Drosophila collection in Los Angeles, California. Drosophila Information Service 93:91-93

Centeno N, Almorza D, Arnillas C (2004) Diversity of Calliphoridae (Insecta:Diptera) in Hudson, Argentina. Neotropical Entomology 33:387-390

Colwell RK (1997) Estimates: statistical estimation of species richness and shared species from samples. Version 5.

Core A, Runckel C, Ivers J, Quock C, Siapno T, DeNault S, Brown BV, DeRisi J, Smith CD, Hafernik J (2012) A new threat to honey bees, the parasitic phorid fly Apocephalus borealis. PLoS One 7:e29639

Disney RHL (1991) The aquatic Phoridae (Diptera). Entomologica scandinavica 22:171-191

Disney RHL (1994) Scuttle flies: the Phoridae, vol. Chapman and Hall, London

Disney RHL (1999) A troublesome sibling species complex of scuttle flies (Diptera: Phoridae) revisited. J Nat Hist 33:1159-1216

Disney RHL (2001) The scuttle flies (Diptera: Phoridae) of Buckingham palace garden. The London Naturalist 80:245-258

Disney RHL (2006a) Scuttle flies (Diptera: Phoridae). Part I: all genera except Megaselia Fauna of Arabia 22:473-521

Disney RHL (2006b) Phoridae, pp. 1-84. In: Sevcik J (ed) Diptera associated with fungi in the Czech and Slovak Republics. Slezské zemské muzeum, Opava

Disney RHL (2008) Natural history of the scuttle fly, Megaselia scalaris. Annu Rev Entomol 53:39-60

Disney RHL, Durska E (2008) Conservation evaluation and the choice of faunal taxa to sample. Biodivers Conserv 17:449-451

Durska E (1981) Phoridae (Diptera) of Warsaw. Memorabilia Zoologica $35: 47-56$

Durska E (1996) The species composition and structure of scuttle fly communities (Diptera: Phoridae) in mature tree stands in pine forests at different stages of habitat degradation. Fragmenta Faunistica 39: $267-285$

Durska E (2001) Secondary succession of scuttle fly communities (Diptera: Phoridae) in moist pine forest in Bialowieza Forest. Fragmenta Faunistica 44:79-128

Durska E (2002) The phenology of dominant scuttle-fly (Diptera: Phoridae) species in the Bialowieza Forest. Entomologica Fennica $13: 123-127$
Durska E (2003) The phenology of Triphleba Rondani species (Diptera: Phoridae) in moist pine forests in the Bialowieza Forest. Entomologica Fennica 14:177-182

Durska E (2006) Diversity of scuttle fly (Diptera: Phoridae) communities in the plantations of moist pine forests of the Bialowieza primeval Forest and the Tuchola Forest (Poland). Biodivers Conserv 15:385-393

Durska E, Kaczorowska E, Disney RHL (2005) Scuttle flies (Diptera: Phoridae) of saline habitats of the Gulf of Gdansk, Poland. Entomologica Fennica 16:159-164

Froese A (1992) Zur Morphologie und Oekologie von Metopina oligoneura Mik (Diptera, Phoridae). Zoologische Jahrbücher Abteilung für Systematik, Oekologie und Geographie der Tiere 119:383-395

Fahrenkamp-Uppenbrink J (2015) Thirty new fly species in Los Angeles. Science 348(6235):646

García-Rojo AM, Martínez-Sánchez A, López R, García de la Vega JM, Rica M, González M, Disney RHL (2013) A mathematical model applied for assisting the estimation of PMI in a case of forensic importance. First record of Conicera similis (Diptera: Phoridae) in a corpse. Forensic Sci Int 231:e11-e18

Grimaldi D, Ginsberg P, Thayer L, McEvey S, Turelli M, Brown B (2015) Strange little flies in the big city: exotic flower-breeding Drosophilidae (Diptera) in urban Los Angeles. PLoS One 10: e0122575

Hartop EA, Brown BV, Disney RHL (2015) Opportunity in our ignorance: urban biodiversity study reveals 30 new species and one new Nearctic record for Megaselia (Diptera: Phoridae) in Los Angeles (California, USA). Zootaxa 3941:451-484

Hartop EA, Brown BV, Disney RHL (2016a) New flies from L.A., the sequel: twelve further new species of Megaselia (Diptera: Phoridae) from the BioSCAN project in Los Angeles. California, USA. doi:10.3897/BDJ.4.e7756

Hartop EA, Wong MA, Eiseman CS (2016b) A new species of Megaselia Rondani (Diptera: Phoridae) from the BioSCAN project in Los Angeles, California, with clarification of confused type series for two other species. Proc Entomol Soc Wash 118:93-100

Karapazarlioglu E, Disney RHL (2015) First record of forensic species Conicera similis (Haliday, 1833) (Diptera: Phoridae) on exhumed rabbit carcasses in Turkey. European Scientific Journal 11:13-16

LeBrun E (2005) Who is the top dog in ant communities? Resources, parasitoids, and multiple competitive hierarchies. Oecologia 142:643-652

LeBrun EG, Plowes RM, Gilbert LE (2009) Indirect competition facilitates widespread displacement of one naturalized parasitoid of imported fire ants by another. Ecology 90:1184-1194

Lindroth CH (1957) The faunal connections between Europe and North America, vol. Almqvist \& Wiksell/ John Wiley \& Sons, Stockholm $\&$ New York

Lintner JA (1895) Report of the state entomologist for the year 1894. New York state museum. Annu Rep 48:339-636

McIntyre NE (2000) Ecology of urban arthropods: a review and a call to action. Ann Entomol Soc Am 93:825-835

McKinney ML (2002) Urbanization, biodiversity, and conservation. Bioscience 52:883-890

Paulian R (1958) Recherches sur les insectes d'importance biologique a Madagascar XXV a XXVIII. Memoirs de l'Institut Scientifique de Madagascar (Serie E) 9:1-19

Prescher S, Büchs W (1997) Zum Einfluss abgestufter Extensivierungsmassnahmen und selbstbegrünender Dauerbrache im Ackerbau auf funktionelle Gruppen der Brachycera (Diptera). Verhandlungen der Gesellschaft für Oekologie 27:385-391

Townes H (1972) A light-weight malaise trap. Entomological News 83: 239-247

Twilley N (2015) L.A.'s Back-Yard Entomologists. The New Yorker. 7 July 2015. http://www.newyorker.com/tech/elements/ losangelesbackyardentomologists. 22 October 2016. 